\title{
Eschatological hope in Haggai: A homiletic reading
}

\author{
Author: \\ Bob Wielenga ${ }^{1}$

\section{Affiliation:} \\ ${ }^{1}$ Unit for Reformed Theology \\ and the development of \\ the South African society, \\ North-West University, \\ Potchefstroom Campus, \\ South Africa \\ Correspondence to: \\ Bob Wielenga

\section{Email:} \\ wielenga@pmburg.co.za \\ Postal address: \\ PO Box 13229, Cascades \\ 3202, South Africa \\ Dates: \\ Received: 18 Mar. 2014 \\ Accepted: 03 Mar. 2015 \\ Published: 28 Apr. 2015 \\ How to cite this article: \\ Wielenga, B., 2015, \\ 'Eschatological hope in \\ Haggai: A homiletic reading', \\ In die Skriflig 49(1), Art. \\ \#1820, 13 pages. http:// \\ dx.doi.org/10.4102/ids. \\ v49i1.1820

\section{Copyright:} \\ (C) 2015. The Authors. \\ Licensee: AOSIS \\ OpenJournals. This work is \\ licensed under the Creative \\ Commons Attribution \\ License.
}

\section{Read online:}

In this article historical research into Haggai's eschatological sayings ( $\mathrm{Hg} 2: 6-9,20-23)$ is combined with a homiletic approach to these two sayings, employing a canon-historical methodology. First, Haggai's silence about the past of the, in 539 вс returned, exiles is investigated. His evaluation of this period will be compared with the one by Ezra-Nehemiah. His emphasis on the present time as decision time with a view to the eschatological future, will be examined. Attention will be given to the role the rebuilt temple played in his prophecies, and the kind of contribution he made to prophetic eschatology. Secondly, the homiletic approach to Haggai's eschatological sayings requires a canonical reflection on their relationship with the New Testament eschatology with a view to strengthen the community of faith's eschatological prospects in the present time.

In hierdie artikel word ' $n$ historiese ondersoek na Haggai se eskatologiese uitsprake (Hag 2:6-9, 20-23) met ' $n$ homiletiese benadering tot albei uitsprake gekombineer met behulp van 'n kanon-historiese metodologie. Eerstens word Haggai se stilswye oor die verlede van die teruggekeerde ballinge van voor 522 v.C. ondersoek en met die beoordeling van dieselfde tydperk deur Esra-Nehemia vergelyk. Sy nadruk op die huidige tyd as beslissingstyd met die oog op die eskatologiese toekoms word bestudeer. Aandag word ook aan die rol geskenk wat die tempel in sy profesieë gespeel het en watter bydrae hy tot die profetiese eskatologie gemaak het. Tweedens vereis die homiletiese benadering van die eskatologiese uitsprake in Haggai om vanuit 'n kanonieke oogpunt op die verhouding met die Nuwe-Testamentiese eskatologie te reflekteer, met die doel om die geloofsgemeenskap se eskatologiese verwagtings in die huidige tyd te versterk.

\section{Introduction}

\section{Background}

At first glance, the postexilic book of the prophet Haggai seems to be of little homiletic value for our present times. He is one of the minor prophets, who almost disappears behind the major ones, and yet receives much attention in church and scholarship. His eschatology does not look strongly developed, but focused on the reconstruction of the ruined temple in Jerusalem. Haggai's sole interest seems to be in his own times; also his two future-orientated prophecies $(\mathrm{Hg} 2: 6-9$, 20-23) are aimed at energising the remnant of Israel, disheartened by the magnitude of the task at hand. However, in this article the eschatological scope of Haggai's prophecies are explored, and some homiletic conclusions are drawn with regard to the preaching of the two passages mentioned. The justification for a homiletic reading of Haggai is that the Bible, including Haggai, has been given to the community of faith for preaching and teaching. In that community the final text has received canonical authority as Holy Writ, and is perceived to be the Word of God, the normative standard for the teaching and preaching ministries of the church (Childs 1985:6-19; Rendtorff 2011:721; Wielenga 2010:709-712). ${ }^{1}$

Together with his colleague, Zechariah, Haggai appears on the scene of the Persian province of Yehud in the 6th century вСЕ at a crucial time. They address with divine authority the Persian appointed governor from Davidic descent, Zerubbabel, and the Zadokite high priest from a highly respected pre-exilic priestly family, Joshua. They encourage them to rebuild the temple in Jerusalem that was destroyed in 586 все. In the second year of the reign of Darius I, in 520 всЕ, Haggai commenced his prophetic ministry, which ended in 518 вСЕ. He concentrates exclusively on the temple rebuilding project in his message. There is no reference whatsoever to altar

1.See McDonald and Sanders (2002) for a comprehensive treatment of the canon debate. See Van den Brink and Van der Kooi (2012:504) about the Heimholung of the Bible in the context of a theological interpretation of Scripture within the context of the church (2012:501-507; and Childs 1985:6-19). 
worship, which had already commenced, according to EzraNehemiah (Ezr 3:2-5), in 537 всE after the first return of the Jewish exiles from Babylon (golah). ${ }^{2}$ It seems as if in Haggai, as well as in Zechariah 1-8, the golah started from scratch with exclusive worship and a cult of God in the temple.

\section{Outline and intention}

The investigations start by comparing the three interdependent time slots we come across in Haggai, viz. the past (pre-520 вс), the present in 520 вс and the eschatological future.

It is worth knowing why the period from 537 to 522 вСЕ is completely ignored in Haggai's book, whilst EzraNehemiah $^{3}$ gives a detailed account of the same period of time. We look into this different approach to the recent past by comparing their views on the role Zerubbabel played in the pre-522 все period; their different treatment of the sacrificial cult in the ruined temple post-537 все will also be investigated. Their differences will prove to be nonessential; they articulate the seriousness of Haggai's stance with regard to this recent past.

We also want to know why Haggai highlights the decisive importance of the present time with complete disregard of the previous period. What was at stake for him here? Haggai does not only have the present time as decision time in view, but he also wants to build up the hope of a glorious future amongst the discouraged returnees; the temple would play a crucial role in the envisaged, eschatological future, in which Zerubbabel did not appear at all. Therefore, some remarks are made about prophetic eschatology as well, in order to inform us in our interpretation of Haggai's eschatological prophecy about the future of the temple under construction.

This article is a report of historical research into Haggai's eschatology. But it also wants to contribute to a homiletic reading of Haggai. That is, his eschatological sayings (Hg 2:6-9, 20-23) are read within the canonical context of the Bible (Rendtorff 2011:717-721). In the community of faith, the Bible in its canonical form is opened and preached (cf. also Greidanus 1988:228-262; Koole 1983:192-246). This also calls for an evaluation of Haggai's eschatological sayings from a New Testament perspective. It is the contention of this article that Haggai's eschatology contributes to an understanding of eschatology in the Bible. This, in turn, should strengthen the eschatological prospects of the community of faith in the present time (in 2015). In this respect, this article tries to combine a historical interest in Haggai's eschatology with a homiletic one in his position as messenger of God's Word even for the present time.

\section{Methodology}

A short note on the methodology employed in this article, is appropriate here. The redemptive-historical approach towards Bible reading is followed (Greidanus 1970:121-130),

2.For the term golah, see Rendtorff (2011:710-713).

3.From here on abbreviated as EN. as advocated by Boda (2004) in his commentary on Haggai. This approach has a canonical and a historical component (Greidanus 1988:228-262; Wielenga 1994:227-232). Following Berkouwer (1966:83-138; cf. Van Keulen 2003:486-494), ${ }^{4}$ the kerugmatic unity of the canon within all its diversity, is presupposed consistently in this article (cf. Strauss \& De Wet 2014:2-3). This canon-historical reading of Haggai is consonant with a postcritical hermeneutical theory in which the intuitive, scientific and contextual reading approaches are taken seriously, not in a conflicting but in a complementary way (Wielenga 1992:31-32).

\section{Time lost: $539-520$ BCE}

We have to understand the role of Haggai in postexilic Yehud against the background of the great revival of Israel, which took place from the days of Cyrus until the end of Nehemiah's time in office (Japhet 1982:68). Haggai's book covers only a small, albeit important, segment of this history. We have to explain its message in the wider context of the postexilic history as we know it from the writings of especially EN (Wielenga 2013). We have to be aware that we do not find in this two-volume book (Boda \& Redditt 2008) a supposedly objective description of historical data, aimed at the making of a history of postexilic Judah (Lipschits \& Blenkinsopp 2003) in modern fashion (Grabbe 1998; Japhet 1991). We find here theologised historiography, aimed at proclaiming a message from the God of Israel, who after the exile was still the same as before, and who remained faithful to his promises of old in Genesis 12:3 (Wright 2006). ${ }^{5}$

\section{Zerubbabel and the time lost: $539-520$ BCE}

An investigation in the role Zerubbabel played in this specific period in postexilic Yehud's history sheds some insight into EN's complex and complicated narrative of that period. Ezra 1-6 is a continuous narrative covering the time from Cyrus' edict with regard to the building of the temple until the celebrations at the occasion of its dedication in 516 все, even though there are internal tensions in this narrative between Ezra 1-3 and 4-6 (Japhet 1991:207-217; cf. Nykolaishen 2008:176-199).

Two years after the first return, in 537 BCE, an attempt was made to start rebuilding the ruined temple (Ezr 3:8). Approximately 17 years lapsed before a second attempt was made (Ezr 5:1). According to EN, Zerubbabel was involved in both events (Japhet 1982:71). His career started long before Darius I became king in 522 все. In Ezra 3, the celebrations followed the reconstruction of the burnt offering altar and the laying of the temple foundation in 537 всE with Zerubbabel and the high priest Joshua officiating. This being the picture we get in Ezra 1-3, the question arises why EN mentions only Zerubbabel's involvement in these events, and passes by his long career before 522 все. Even afterwards, he scarcely

\footnotetext{
4.See Van den Brink and Van der Kooi (2012:496-501) for a systematic-theological justification of the approach employed here.

5.The promised nation descending from Abraham, the promised land, the promise to be a blessing to the nations.
} 
receives a mention in EN. Moreover, the name Shesbassar is brought up (Ezr 1:11; 5:14) as the leader of the returning Jews in 539 все, so creating confusion around Zerubbabel's identity and participation in the proceedings, narrated in Ezra 3. EN's evaluation of Zerubbabel's role is decidedly low-key.

Several scholars have, therefore, denied that Zerubbabel played a role long before 520 все; he must have arrived in Jerusalem shortly before this date in the wake of Darius' ascension to the Persian throne and his reorganisation of the imperial administration. They reckon that the cultic celebrations in Ezra 3 refer to the completion of the temple in 516 все (Boda 2004:28). We do not know much about altar worship in Jerusalem before the arrival of Darius on the scene.

In response to this position we refer to Ezra 5:11-17, where a letter of the Jewish elders is mentioned, documenting that the temple building project is not a novel undertaking, but one already permitted long before by king Cyrus, who stipulated that the temple be built as a place where sacrifices had to be presented (Ezr 6:3). Even the name of Shesbassar, already faded away from their memories, is mentioned to give authenticity to this claim. This supports the contention that altar worship commenced in 537 BCE, with great joy and celebrations, after the completion of the laying of the temple foundations. ${ }^{6}$ In Ezra 3 not 516 вСе but 537 все is the year in view (Assis 2008:4; Japhet 1982:92, 96).

In Japhet's (1982:93) opinion that does not mean that historically Zerubbabel had already arrived in Yehud in 539 вСЕ; no, he entered the scene in the wake of Darius on a wave of politically instigated messianic hope, being the scion of the Davidic house (Japhet 1991:219). But the narrative, as told in Ezra 1-6 from a considerable time distance, lets the reconstruction period start in $537 \mathrm{BCE}$, and replaces the halfforgotten Shesbassar with Zerubbabel, thereby stressing the coherence and continuity of the restoration history. Nevertheless, Zerubbabel plays not a central but peripheral role in EN. It was the elders (Ezr 5:5, 14; 6:14) of the golah who took centre stage, just as they also did in Ezra 7-10 (Eskenazi 1988). In EN's worldview there was no room for political aspirations tied to the Davidic monarchy (Karrer-Grube 2003:143). It stressed that the present political dispensation was the outworking of the divine will (Is 42:9; 44:28; 45:1; Ezr 1:1-4; 6:22; cf. Japhet 1982:71-73; Kessler 2002:261). Therefore, in EN's historiography the elders play a more important part than leaders like Zerubbabel (Eskenazi 1988:40-53; Japhet 1982:80-83). In short, there was altar worship since 537 вСЕ, but Zerubbabel's role was inserted into its narrative by EN.? EN's introduction of Zerubbabel in the pre-522 вСЕ period was to strengthen the golah's claims of temple rebuilding

6.See Hurowitz (2010:292-294) about celebrations after laying the temple foundations in the ancient Near East. See also Schaudig (2010:150-153) and Boda (2010: 313-314), who refers to 2 Chronicles 3:3; 8:16. The ancient Near Eastern temple $313-314)$, who refers to 2 Chronicles $3: 3 ; 8: 16$. The ancient Near Eastern temple
culture exercised its influence on the Jewish understanding of the importance of culture exercised its influence on the Jewish understanding of the importance of
laying temple foundations in postexilic Yehud. There must have been cultic worship.

7.Japhet's (1991:223) suggestion that EN accepted Haggai's testimony about Zerubbabel laying the temple foundations in $520 \mathrm{BCE}$, but backdated it to $537 \mathrm{BCE}$, is plausible. in the present time after 522 вСЕ. EN's interest was not in the past but in the present. In this sense he comes close to Haggai's perspective on this matter.

\section{Worship during the time lost}

Haggai's perspective on the pre-522 все history of Yehud is therefore not that different from that of EN. Both books were, of course, published in different historical circumstances with different sets of questions to be answered. The book of Haggai must have been published shortly before 516 все 8 (Boda 2004:29-30; Kessler 2002:29-53, 244). EN was published late in the 5th century $\mathrm{BCE}$ at some distance from the narrative it contains (Floyd 1995:470-490; Japhet 1994: 198-216; Kessler 2002:29-50). Nevertheless, their narratives are not really in conflict with one another with regard to the role Zerubbabel played pre-522 все. There is also more agreement with regard to the pre-522 cultic worship in the ruined temple than is usually assumed.

Haggai focuses exclusively on the period of temple building from 520-516 все, and has no interest in what went before. For him the present time is decisive, a turning point in the postexilic history of the golah, ${ }^{9}$ unlocking the eschatological future (Hg 2:6-9, 21-23), which was linked with the restored temple. From this perspective the pre-522 BCE altar worship formed part of a practice people had to repent from, if they wanted to have a future with the God of the covenant of old (Gen 12:3). ${ }^{10}$

Haggai must have known of the past attempt to restore the temple, and the re-erection of the burnt offering altar. The following are an indication thereof: In Ezra 1, 11 the restoration narrative starts off with the edict of Cyrus, in which the permission for rebuilding the temple was confirmed. According to the dictates of ancient Near Eastern conventions, a temple could only be rebuilt and a destroyed altar only be restored at divine instigation and royal initiative (Boda 2010:303-318; Hurowitz 2010:281-302; Kessler 2010: 357-380). Cyrus' edict contains both elements: the God of Israel stirred the king's heart, and the king as God's servant (Is 44:28), issued the command to rebuild the temple on its ancient foundations. The returnees could not have disobeyed the king by not starting to restore the altar and temple (Lux 2009:126). Disobeying a royal decree, written down and archived as well (Wielenga 2013:2), was no option in those ancient times. In conclusion, Haggai, intentionally, did not want to mention the previous time at all.

8.Even though the infrastructure for publishing written texts was not well developed early after the exile in sparsely populated Yehud (Floyd 2008:224-226), the relatively great numbers of Levites (Ezr 2:40-60; 8:15-20) among the returnees made this possible (cf. Van der Toorn 2007:79-81,108-141).

9.Note the emphatic 'and now' in Haggai 1:5; $2: 4,15$. Now is the time of grace which opens the future (Klement 2012:180-181).

10.See Rose (2012:185-186) about the outlook of Haggai's colleague Zechariah $(1: 1-6 ; 7-8)$ on the recent past of the returnees.

11.See Japhet (1991:209-213) about the differences between the two versions of the edict in Ezra 1 and 6 . She considers, for good reasons, the Ezra 6 version the original one, the Ezra 1 version is a theologically edited one from EN's final perspective. 
Throntveit (1992:22) points out that the narrative of the return from Babylon to Yehud has been structured along the lines of the exodus ${ }^{12}$ and the conquest narrative in the Pentateuch (cf. also Japhet 1991:213). Two clear examples can be mentioned, ${ }^{13}$ namely after entering the promised land the Israelites had to build an altar on Mount Ebal (Dt 27:1-8), and had to write the decalogue on plastered stones (Miller 1990:190-193). The nation had to be founded on the basis of sacrifice and law, as spelled out in the Deuteronomic tradition. Safety and security in the promised land, also after their return from exile, were tied up with altar worship and obedience to the Mosaic law (Wielenga 2013:4). EN intended us to believe that the 537 все celebrations are described in Ezra 3. Haggai, who was familiar with the Deuteronomic traditions (Kessler 2002:100), must have been familiar with the new exodusconcept, as formulated in 2 Isaiah (Is 43:19; 48:6). It is most unlikely that no altar was built and no worship commenced after the return in 539 все. Haggai chose to disregard the time under review and to focus exclusively on what God wanted the golah to do in the present time with a view on the future, in which the temple was going to play a crucial role.

There are also some internal indications in Haggai of the existence of a well-established, institutionalised altar worship without the temple being restored (Japhet 1991:228). This underlines Haggai's firm commitment to the present and the future. Probably at the occasion of the New Moon festival ( $\mathrm{Hg} 1: 1$; cf. Boda 2004:90, 118; Kessler 2002:115) Haggai started his prophetic ministry. The people gathered at the premises of the ruined temple to bring the prescribed sacrifices. Also in Haggai 2:1 the date reminds us of several festivals ( $\mathrm{Lv} 23: 23$, 33; Nm 29:1) that took place during this month. The centrepiece of these festivals was the sacrificial worship around the burnt offering altar. Haggai made use of one of these occasions to confront the golah, gathered together for worship, with God's rebuke of negligence of his dwelling place in front of them, and so of the covenantal relationship between them. In Ezra 3 the altar is said to be erected to function during the festival of booths, a festival to commemorate and celebrate God's faithfulness during their journey, and return, to the promised land. In Haggai's time, people were used to visit the festivals in order to fulfil their cultic duties. The altar must have already been there for a longer time. The pilgrimage tradition did not simply start just overnight in 520 вСЕ. Without an established sacrificial ministry a pilgrimage to the ruined temple premises would have been meaningless.

Also, in Haggai 2:10-14, where Haggai refers to a torah given by the priests about the efficaciousness of sacrifices, the assumption is that the altar worship had not been recently restored, but that the priests had already been officiating at the altar for a long time (Japhet 1991:228). If the burnt offering altar had been rebuilt just a couple of years earlier with the

12.The return from exile as a new exodus is well established in prophetic literature (Gowan 2000:26).

13.Japhet (1991:212-213) also refers to the financing of the temple. In Ezra 1 the model developed in Exodus 25 is followed: the project will be financed by private donations, while in Ezra 6 the imperial treasury is responsible for the financing. priests only recently installed to officiate there, the fact that the prophet consulted the priests would not have been mentioned without any explanation; clearly it was the usual practice to consult the priests in such matters. This is confirmed in Zechariah 7:3, where pilgrims visit the house of God, still in ruins, and consult the priests. In conclusion, the altar worship had been functioning since 537 вСE whilst the temple was not restored until 516 всЕ. Against this background of an ongoing altar worship and priestly ministry in the desolate temple since 537 вСЕ, Haggai's insistent focusing on the present and the future should draw our attention. He sought a complete break with the recent past, because it was blocking the future, in which Zerubbabel would also not play any role.

\section{The present time}

To understand the seriousness of the spiritual confusion the golah was caught up in around $520 \mathrm{BCE}$, we need to realise that the initiative to restart the temple rebuilding project came from God, who stirred the king's heart, and commissioned his prophets to make appeal to the people to restart the restoration under the leadership of Zerubbabel and Joshua (Hg 1:1; cf. Ps 102:13; Kessler 2010:362). Amongst the people themselves there was no movement in that direction, just the opposite. Also their two highly rated leaders were included in the stinging rebuke the prophets were delivering here with divine authority. The question arises why God made the effort to initiate this project amongst a people ${ }^{14}$ who were not interested in it in the first place ${ }^{15}$

The people felt indifferent towards the temple since external and internal enemies forced them to bring the project to a standstill (Ezr 4-5). This became an excuse for them to prioritise their own economic concerns at the detriment of God's interests. This did not trouble them, because they could continue their worship around the burnt offering altar at the premises of the ruined temple, where priests were officiating. The sacrificial ministry in line with the Torah seemed sufficient to them to please God.

It would be good to also take into account 3 Isaiah's sharp critique of the spiritual corruption having taken root amongst the golah since 537 все (Is 57-59); ${ }^{16}$ the prophecies recorded here must have been uttered in the same early Persian era (Blenkinsopp 2003:45; Westermann 1969). It is no surprise, then, that the temple did not feature strongly, if at all, in the people's spirituality. This contemporaneous prophetic voice firmly creates the impression of a growing division amongst the golah between a minority of God-fearers trembling for his Word and the majority who continued their sacrificial duties, but without any authentic concern for God and his

14.See Boda (2004:89) for the expression 'these' people. See also Koch (1967:52-66) on Haggai 2:10-14; and for a different view Wolff (1986:42).

15.Kessler (2010:261) differently refers to a possibly positive attitude of the golah: people were waiting for divine authorisation to start the project. See also Assis (2009:256-272); and Wolff (1986:24).

16.Schmitt (2003:186-198) brings up archaeological evidence that after 586 BCE until the revival in 520 BCE worship of foreign gods just continued: terracotta figurines, dedicated to those gods and kept in shrines, have been found at several places in dedicated to those gods and kept in shrines, have been found at several places in
Yehud with exception of Jerusalem. No iconoclasm had taken place after 539 BCE (2003:191). Cf. Ezekiel 13:18 (Zimmerli 1969:297). 
will expressed in the Torah (Is 57:13, 17-21; 66:1-3; Wielenga 1998a:114-115). ${ }^{17}$ In 3 Isaiah we find allusions to Jeremiah 7 and 26 and Ezekiel 16 and 23, identifying pre-exilic patterns of syncretism amongst the returnees (Is 57:5-13; 58:1-7; 59:2-15; 65:2-3; Blenkinsopp 2003:160-190). There were good reasons for EN to emphasise the external boundary between the golah and the people who remained in the country during exile, either from ethnic Jewish or from mixed descent in Samaria (Knoppers 2007:305-321). ${ }^{18}$ The continuance of the covenant and the survival of Israel as God's people were at stake. How serious the situation really was, is shown by Haggai in 2:10-14.

We could call his consultation of the priests a prophetic symbolical act (Kessler 2002:212-213), used as a teaching aid in his prophetic sermon ( $\mathrm{Hg} 2: 10)$. It does not really matter whether the impurity pointed out must be seen as moral (Hildebrand 1989:154-168) or as ritual (Koch 1967:63-64) or as both. Haggai $(1: 1,12)$ clearly described the situation that existed before the repentance of the people after his first public appearance. In Haggai 2:15 he declared their whole previous life, including their altar worship impure, that is it was not up to the standards of a holy God because of their neglect of his house, the temple in Jerusalem. This neglect was the root cause of the moral and religious decline of the majority of the golah, amongst whom many of the priests. They could not fall back on their continued altar worship. Their sacrifices were powerless to cleanse them from sin and keep them in the right relationship with God, because they were brought by unclean hands, representing indifferent hearts. Haggai's verdict was backed up by the Torah, expressing God's authoritative view on the matter. ${ }^{19}$

Haggai understood the plight the golah was suffering ( $\mathrm{Hg}$ $1: 5-6,10-11 ; 2: 16-17)$ as a consequence of the breaking of the covenant, concluded on Mount Horeb ( $\mathrm{Hg}$ 2:5). In Leviticus 26:3-5, 14-17 and Deuteronomy 30:1-10 the fruits of (dis-) obedience to the covenant were spelled out: blessings and curses. The basic feature of the covenant was the worship of only one God, as expressed in the first commandment of the decalogue, Who dwelled in the midst of his people at the place chosen by him (Dt 12:10). Neglecting the place where this God wanted to dwell amongst them and be worshipped, was interpreted by Haggai as violating the covenantal relationship with dire consequences, as the people had already been experiencing for some time. The economic hardship, threatening the basic necessities of their life, was a curse from God, which also endangered their eschatological future as promised in the prophetic traditions recorded in 2 and 3 Isaiah $^{20}$ (Wielenga 1998a:108-117). Before God's merciful initiative and his successive command $(\mathrm{Hg} 1: 8)$ the returned remnant of Israel had no future at all as people of

17.In Isaiah 66:1-3 we do not find a polemic against temple building, as Japhet (1991:233-236) contends; cf. Blenkinsopp (2003:294-295); Westermann (1969:412-413).

18.Differently: Harrington (2008:99-101).

19.Cf. Leviticus 7:11-15; 22:1-9; Numbers 19:22; Deuteronomy 17:8-13.

20.Cf. Isaiah 42:9; 43:18-19; 56:8; 59:21; 60:22; 66:18.
God. That future could only be accessed if land and people would be cleansed and healed, as graphically depicted in Ezekiel 47:1-12 (Wright 2001:356-357). Even though the exiles had returned from exile in 539 все, God's return (Ezk 43:4) was still pending, his house not yet ready to receive him, his presence amongst them not yet being fully appreciated by his own people.

Against this background, the turnaround of the golah, narrated in Haggai 1:12 using deuteronomic phraseology (Dt 4:25-32; 10:12, 20; Kessler 2010:366, 371, 378), must have come to the prophet as a miraculous surprise, observing the instantaneous results of his prophetic preaching (Kessler 2002:141-154; Meyers \& Meyers 1987:44). It meant the healing of the ruptured covenantal relationship. This opened the way for the return of God and his blessing (Dt 30:1-10). It also created space for the future to break in into the present.

\section{From the present to the future}

Before going into Haggai's eschatological sayings about the temple and the seal ( $\mathrm{Hg}$ 2:6-9, 21-23), we first need to discuss the temple theology in Israel's traditions, and secondly, prophetic eschatology in the Old Testament. ${ }^{21}$

\section{Preliminary remarks}

The question raised earlier was why God was so committed to the rebuilding project in spite of the lukewarm response by 'these' people ( $\mathrm{Hg} 1: 2)$, in bringing it about. The answer is found in Haggai 1:8, but is embedded in a broader biblical-theological framework, of which Haggai must have been aware, standing in the pre-exilic prophetic tradition (Kessler 2002:100; Tollington 1993:79). There are differences in interpretation of this verse (Boda 2004:91-92; Kessler 2002:134-135), but the message is nevertheless clear. A completed temple will be received with pleasure by God as his dwelling place, comparable with the pleasure he expressed, when sacrifices were burnt on the altar, and their aroma went up to heaven as in Leviticus 1:10 (Assis 2008:7). It would meet with his approval. There were no rituals needed, known from the contemporary Near Eastern temple building culture, to persuade God to return to the temple (Kessler 2008:41-58). In line with the Zion-theological and deuteronomic traditions, the only conditions for God's return to his own dwelling place on earth were, in Haggai's view, obedience to the Torah and loyalty to the covenant's demands, being fruits of repentance (see Ezk 43:10-11; cf. Boda 2003:68). Their commitment to temple reconstruction would be proof of the sincerity of their repentance. In Ezekiel 37:26-28 this is perceived to be part of the new covenantal relationship God is going to establish between him and the remnant of his people with the firm promise that 'the restored presence of God in a cleansed Israel will have its effect on the nations' (Wright 2006:338; 2001:313-314).

21.Gowan (2000:4-20) underlines the importance of Zion as holy place because of the temple built there. The emphasis should be, rather, on God who chose to reside temple built there. The emphasis should be, rather, on God who chose to reside
there on earth. Not the glory of the residence but of the Resident is at stake in Haggai. 
In the final analysis, his return to dwell amongst them in the temple is an act of grace (Lux 2009:228), even more so, if we take also into consideration the harsh words spoken in 3 Isaiah against the continuing pre-exilic patterns of idolatry found after the exile in the early Persian period amongst the majority of the golah (Is 57:1-13). Haggai's central message focuses on God's gracious presence in the temple as the only hope for the future. ${ }^{22}$

This presumes a certain theological conceptualisation of God's dwelling on earth in a man-made temple, which we already find long before the exile at the time of erecting the tabernacle (Ex 25:8; 29:44-46; 40:34-35), but also when Solomon dedicated the first temple to God (1 Ki 8:27-30). The holy God of Israel, the Lord Almighty, ${ }^{23}$ Lord of the nations, is truly present in the temple in Jerusalem. It is not first of all the place for cultic worship, even though that was a crucial function of the temple. The temple is the centre of God's royal presence on earth, from where he executes his sovereign power over the nations, and rules with supreme authority over his creation (cf. Ezk 43:7-9). From Zion shalom will go out over the earth (Is 2:1-5; 60-62; Ezk 47:1-12; Dekker 2009:112-113). As Haggai himself points out, the temple as residence of God played a crucial role in God's redemptive history, also after the exile, with the remnant of Israel returned to the promised land $(\mathrm{Hg} 2: 6-9,20-23)$. The golah's delaying of the temple reconstruction betrayed a profound lack of understanding of the basics of Israel's pre-exilic faith traditions. This inevitably reflected badly on the teaching ministry entrusted to the priests. There was good reason for the high priest to be cleansed and rededicated to his office in one of Zechariah's night visions (Zch 3:1-5; cf. Pola 2003:163).

\section{Prophetic eschatology}

Haggai's perspective on the small beginnings of the reconstruction work reveals his future-orientated vision for the rebuilt temple. The people are taught to think forward towards the future ( $\mathrm{Hg}$ 2:1-9). One could speak here of the eschatology of Haggai (Van Rooy 1988). All sorts of elements, characteristic of prophetic eschatology, we find back in Haggai 2:6-9 and in 2:20-23. The coming of God's shalom, of his judgement, of his salvation, potentially messianic expectations originating from 2 Samuel 7, plus waiting for God's imminent fulfilment of his promises - these are all themes touched upon by Haggai in a time of spiritual crisis and of socio-economic upheaval in Yehud. Engagement in the complicated debate on prophetic eschatology, its terminology and definition in the Old Testament, falls beyond the scope of this article. ${ }^{24}$ Some short remarks must suffice.

22.See also Exodus 40:34-35; 1 Kings $8: 6-10$ on the relation between the presence of God's glory and the Ark of the Covenant before the exile (Pikänen 2010:270-273 Rendtorff 2011:522-525).

23.This name appears 12 times in Haggai 1-2. It is connected with the Ark of the Covenant as throne of God, located in the Holy of Holies of the sanctuary (Dekker 2009:111; Meyers \& Meyers 1987:19). It was portable, reminding the people of God's mobility: He could leave the temple and return to it (Ezk 10:18; 43:3-5; Carvalho 2008:131). Of course, the ark itself does not reappear after the exile. See also Rendtorff (2011:514-518, 521).

24.For the discussion on Old Testament eschatology, see amongst others Grabbe and Haak (2003); Gowan (2000); Noort (1984); Peels (1999); for references to the debate on the terminology and methodology of eschatology, see footnote 26
The source of prophetic eschatology is to be found in Israel's belief in God, as witnessed in almost all tradition streams of the Old Testament (Peels 1999:32-38). It is based on the well-founded hope that this God would be present amongst his people also in the troubled times ahead, and even in the future beyond, fulfilling faithfully the promises of old he has made. ${ }^{25}$

Of course, prophetic eschatology has to be distinguished from apocalyptic eschatology, the origins of which can be traced back to postexilic prophetic voices in 2 and 3 Isaiah, Zechariah 9-14 or Daniel (Hanson 1975:251; Witherington 1999:145, 217, 237; Wright 1992:281-299). Prophetic eschatology remains within the boundaries of this-worldly history, integrating God's interventions in this world into the structures of space-time history. Apocalyptic eschatology reaches imaginatively beyond the realm of this world into an other-worldly reality. ${ }^{26}$ This is clearly not the case in Haggai's prophecies, even though the differences between both types of eschatology must not be exaggerated. Haggai's use of the shaking of the cosmos metaphor preludes the literary genre of the apocalypse. ${ }^{27}$

\section{Into the future: God's house}

To stir up the flagging spirits after only one month $(\operatorname{Hg} 1: 1 ; 2: 1)$ of labouring to clear the rubble and to find the foundations of the first temple with all the festivals going on in the 7th month, Haggai gave the people, assembled on the last day of the festival of booths ${ }^{28}$ (Boda 2004:118), a rousing speech of encouragement. ${ }^{29}$ Two elements in this speech stand out: the reference to the covenant concluded in the Mosaic era on Mount Horeb, when God's presence was visible amongst the people in the pillars of fire and cloud; and the reference to God's intervention in history in the immediate future, in which the present temple under construction would play a pivotal part. God's presence in the temple links this imminent intervention to his covenanting actions in Israel's history at Mount Horeb ( $\mathrm{Hg}$ 2:5). Redemptive history is perceived by Haggai as continuous and coherent in spite of the contingency caused by the exile (Kessler 2008:25; Wielenga 1998b:333-348). Because of his faithfulness to his promises made in the context of the mosaic covenant, God does not leave the remnant of his people behind on his journey into the future. God opens the future for them, in which there is also space in the temple for the nations and their treasures $(\mathrm{Hg}$ 2:7-8). Haggai clearly presumes a duality between the eschatological future with its temple originated

25.Cf. Preuss, Jahwehglaube und Zukunfterwartung (1968) quoted in Noort (1984:14).

26.See the discussion about definitions between Grabbe and Collins in Grabbe and Haak (2003:2-43, 44-53, 74-84, 107-133). Even though Grabbe touches on important points, we generally follow Collins.

27.Cf. Witherington (1999:105) about the change in prophecy after the exile. There was an 'increase of visionary and apocalyptic elements in prophecy'. Berquist (1995:177-179) also sees the early postexilic period as the beginning of the rise of apocalyptic prophetic literature. Contra Grabbe in Grabbe and Haak (2003).

28.Cf. Leviticus 23:33-43; Deuteronomy 16:13-17; and also Exodus 23:16; 34:22 (where the link with the harvest is made).

29. It was not a coincidence that Solomon dedicated the first temple during the same festival, 1 Kings 8:2 (Boda 2004:120). 
cosmic peace and the present of God's grace, evidenced by the turning around of the people's material wellbeing. But the two stages in redemptive history are interlinked in one and the same stream of covenantal history, and not dualistically contrasted with one another, as happens in apocalyptic literature.

Lessing (2010:253-257) asserts that the shaking of heaven and earth is a theme first developed by Amos, who experienced a heavy earthquake in his life time. Later it was taken up and elaborated on in the book of the twelve prophets in the context of God's judgement either over the nations or, controversially, over Israel itself. In the prophetic tradition ${ }^{30}$ this metaphor has been transmitted together with the 'Day of the Lord' prophecies with their warfare phraseology, pointing to God doing battle against his enemies in the eschatological future. Haggai certainly alludes to this tradition, but updates this theme for his own purposes; he leaves out the warfare imagery, for instance, and the emphasis on judgement is more implicit (Kessler 2002:185-190). Haggai stresses that building the ruined temple is building for the future, when God's peace will cover the earth, spreading out from his residence on Zion ( $\mathrm{Hg} 2: 9,22)$. One could argue that Haggai indirectly refers here to the eschatological prophecies of his contemporary that we find in Isaiah 60-62 (Van Rooy 1988:60), uttered in more or less the same postexilic context (Blenkinsopp 2003:64-89). Both prophets are complementing one another.

The outcome of God's cosmic intervention in history is a great reversal in the fate of the nations, which will benefit the temple, God's residence from where he exercises his power. Glory will be brought to God, dwelling in his sanctuary. The purpose is not that Jerusalem as such will be glorified (contra Gowan 2000:24-26), even though it would benefit from this great reversal; its greatness comes from God being present there (Dt 4:5-9), and depends on its wholehearted obedience to his law. ${ }^{31}$ Rebuilding the temple as expression of their obedience will make the golah reflect the glory of the God who dwells in it. God's glory, revealed in the temple, will be reflected in the darkness of the world of nations, and after his intervention, attract them to the temple to bring their wealth and treasures as tribute to the Lord God Allmighty (Is 60:5; 61:6; 66:20; Wielenga 1998a:116). That this will be beneficial for the nations as well, is an issue raised in 3 Isaiah (60-62) ${ }^{32}$ In short, the shaking of the cosmos would bring in a new future, never known before, the message of which intended to encourage the dejected golah to persevere in the present with their God given assignment.

Attempts to identify the fulfilment of this prophecy in the short term, and to localise it in objective historical events

\section{$30 . T o l i n g t o n$ (1993:224) refers to Psalm 46:2-6 as a possible source of this tradition.}

31.In Hebrews 12:25-26 is the shaking motif of Haggai 2:6 referred to in the context of a divine warning.

32. Haggai alludes here to prophecies about pilgrimages of the nations to Zion (Is $2: 5 ; 45: 14 ; 60: 3-9$ ). in the (early) postexilic era, ${ }^{33}$ do not seem to take seriously enough the eschatological nature of Haggai's prophecy. ${ }^{34}$ The reference to 'a little while' ( $\mathrm{Hg}$ 2:6) fits the eschatological language of the postexilic prophets. The expression stresses the imminence and the urgency of God's intervention, whenever it would take place at whatever time in the future. ${ }^{35}$ But with caution we could say that the cosmic peace resulting from this divine intervention $(\mathrm{Hg} 2: 9)$ might already be anticipated, piecemeal, in the present spacetime history and may be, tentatively, identified and named, encouraging the people to expect with patient impatience the full realisation of this eschatological promise, whenever this might be. Only on this condition could one point, provisionally, to concrete events in the postexilic Persian era as temporary fulfilments of this promise, evoking a great longing for the definite realisation of what God had promised. One has to avoid a realised eschatology type of interpretation in which there is no room for eschatological reservation, which opens up history to the future. ${ }^{36}$ Later on this theme would be taken up in the apocalyptic literature (Collins 1987). But without the temple being rebuilt no cosmic peace would arrive, because there would be no God Almighty in their midst, fulfilling his promise of cosmic peace spreading out from the temple. No glory would shine in the darkness, leading the nations home to Zion. The temple reconstruction, however small and insignificant it might seem to be, unites past and future of redemptive history in the present, creating hope amongst the people. It is a significant step on the long road into the future. But Haggai adds another eschatological piece of information that has to be taken into account.

\section{Into the future: God's seal}

We cannot go into the lengthy discussions about Haggai 2:20-23 and its many interpretations. We restrict ourselves to a probing of the eschatological significance of the famous Zerubbabel passage. How does Haggai link Zerubbabel with the golah's future? Is he expected, as the hope of Israel, to act decisively in God's name, realising his promises? Will he introduce the messianic age in Yehud (Collins 2003:74-84; Kessler 2002:238, 260-261)?

We follow Rose's (2000:230-232) approach to these questions. He asserts that the crucial term seal does not refer to

\footnotetext{
33.It is said to refer to material wealth as the temple treasures, returned by Cyrus or in the ancient Near East. One could raise the question whether the rearrangement of the political world map is literally or metaphorically meant. Even though it was not Haggai's intention to predict power changes in the ancient Near East, the wish for transformation of the political realities of the day must have given birth to this eschatological language of hope. But wishing does not belong to the vocabulary of this language.

34.The reference to cosmic shaking belongs to the eschatological language of hope, effecting trust in God and his promises; it is not about a reporter's account of a future event, which gives rise to speculation (Bauckham \& Hart 1999:73-108; Berkouwer 1972:19, 255; Van Keulen 2003:604-606). It signifies the radical change God's intervention is going to create.

35.It is not an indication of time in terms of human chronology. Kairos, and not chronos, would be the correct reference. The thesis we could speak of here of Nah-erwartung, which caused a crisis amongst the people because of supposedly delayed fulfilment, finds no evidence in the text.
}

36.Cf. Van den Brink and Van der Kooi (2012:647-652) on biblical eschatology. 
delegation of authority, ${ }^{37}$ as the possible translation 'signet ring' could suggest. The (in this context) better translation, seal, refers to the highly personal value Zerubbabel, God's chosen servant, represents in God's eyes. He was precious to him like a seal to his royal owner. Neither in Jeremiah 22:24 nor in Haggai 2:23 does the seal-metaphor refer to messianic kingship (2000:237-238). The point made in Haggai 2:23 is that God will make Zerubbabel like his seal, not that he will give him his seal, which could be interpreted as a delegation of authority, enabling him to go on God's mission as his ambassador. The phraseology that is used prevents such an explanation. Haggai does not speak about any role Zerubbabel has to play in God's shaking of the heaven and earth, and in its aftermath, the rearrangement of the political and military map of the world of his times (2000:239-240)..$^{38}$ According to Haggai 2:23 Zerubbabel does not play any role at all; he just disappears from the scene. Haggai's colleague Zechariah also does not promote Zerubbabel as royal player on the scene of early Persian history (Rose 2013:215-216). The only one who will be honoured as king of the earth is God himself, the Almighty, and Lord of the nations. In Zechariah 9, representing a later stage of prophetic eschatology, the prophet describes God as the King, who approaches from the North as a warrior, but Who is welcomed in the South, in Jerusalem, as a man of peace, gentle and riding on a donkey, righteous and having salvation. ${ }^{39}$ In conclusion, Haggai has nothing to say about any political-messianic role of Zerubbabel in the near future. It would also conflict with his acceptance of the Persian dispensation as God willed. He concurs with EN.

What God does promise is that in the coming cosmic upheaval with its rearrangement of power relations in the ancient Near East, his people will be safe and secure. The Persian appointed governor of Davidic descent, Zerubbabel, represents the golah, the true Israel of God, his holy seed, in the divinely willed political dispensation of his time. As the people's representative he will be the beneficiary of God's eschatological intervention in a way not described by Haggai, just like Joel 3:16 did not spell that out in a prophecy which reminds us strongly of Haggai's prophecy (Rose 2000:242-243). Whatever will happen in the future, God will look after him or them like a king cares for his seal. In line with the historiography of EN, Haggai also did not entertain messianic-political hopes, supposedly stirred up by the appearance of a scion of the Davidic house in the turbulent times of the moment in the Persian empire. Zerubbabel disappears from the scene unnoticed, unlamented. He served God's purpose with him to be a teaching aid in a prophetic sermon of hope and encouragement. The hope of the people was not supposed to be settled on Zerubbabel and a specific plan of action, but on God who was in control of the history of his people

37.So do Boda (2004:165); Kessler (2002:229-233; 2010:367-369); Von Rad (1965:294-295).

38.At this point we have to guard against speculative interpretations of events in the political history of the ancient Near East. It is firstly metaphorical language of hope.

39.In the New Testament this verse received a messianic update: God in Jesus is the King Who is going to fulfil all his promises to the full (Mt 21:1-11; In 12:12-19). and of the nations. They had politically (by settling for submission to the Persian king and for integration in this God-willed dispensation) placed their hope for the future in him (De Jong 2002:243).

\section{Homiletic considerations}

The book of Haggai does not only form part of the Hebrew Bible, but also of the Christian Bible with its two Testaments (Rendtorff 2011:740-756). This prompts a Christian reader to consider the ramifications of its inclusion in canonical Scripture. Boda (2004:37-60) explicitly confronts himself with the hermeneutical question of the application of Haggai to the present time from a Christian perspective, in which the New Testament plays a normative role. Following the lead of Boda in opting for a redemptive-historical hermeneutic, with emphasis on the two eschatological passages in Haggai 2:6-9, 20-23 (2004:128-130; 165), we want to explore the homiletic scope of these eschatological sayings of Haggai in the context of the present community of faith. The leading question will be whether these passages can still play a role in the teaching and preaching ministries of the church.

\section{Haggai's eschatology summarised}

Before Haggai's eschatology is homiletically explored, his prophetic teachings on this point will be summarised to guide us in our discussions.

Haggai's eschatological outlook is rooted in the past of the redemptive history. God's covenantal promise always to be the God of his people, who are to respond to his demand of worship with obedience, anchors the future of God's people throughout redemptive history, and through them the future of this world. The future, embedded in God's promises of old, shapes the present in Haggai's prophetic preaching, but it is rooted in the past.

Eschatological hope is sustained by the reality of God's residing on earth amongst his people in the temple of Jerusalem. In Haggai's outlook the temple will be the epicentre of the shaking of the cosmos, initiating the rearrangement of the political world map, with as a result the peace that will spread out from the temple. But whilst that will happen in God's time at his good pleasure, the people's responsibility is to break with their past and to commit themselves to God's future by rebuilding the temple. How insignificant their work might be in their own eyes, nothing should be looked down upon; nothing must be rejected as worthless for the age to come.

The seal-metaphor is employed to nourish the hope that God will providentially take care of his people in the turbulent times ahead throughout the shaking of the cosmos and its aftermath, so that they will receive the fruits of God's intervention, that is the pilgrimage of the nations to the temple, bringing glory to God, and initiating peace on earth. 


\section{Eschatological hope in the New Testament}

Our research is focused on Haggai's eschatological preaching in his own early postexilic context. But we want to explore, however short it has to be because of the constraints of space, its homiletic significance as part of the Christian Bible as well. ${ }^{40}$ This implies that we have to look at the Christological roots of biblical eschatology. It has been argued that Haggai's prophecies do not contain messianic references or allusions. ${ }^{41}$ His contribution to our understanding of the eschatological message of canonical Scriptures must not be looked for in this direction. The following points for discussion will be addressed. First, we consider the first statement we formulated above with regard to the interdependency between past and future in redemptive history. This has relevance for the structure and content of eschatology in a biblical light. Next, the second statement, touching on the central importance of God's residing on earth in the temple for sustaining eschatological hope, will be discussed. Lastly, we look into an eschatologically informed way of life for the church, journeying as pilgrims on earth in the in-between times, in hope against hope.

\section{Christological grounding of eschatology}

The apostle Paul is quite clear in his famous 15th chapter of the first letter to the Corinthians: one cannot speak about the eschatological future of Israel, and the world of nations, or about cosmic peace, without pointing to the bodily resurrected Jesus Christ as the source and foundation of this hope. In Romans 8:20-22 he is no less firm in his conviction that the future of creation, subjected to frustrations and bondage to decay and groaning as in the pains of childbirth, is grounded in the death and bodily resurrection of Jesus Christ in the 1st century CE (Versteeg 1975:85-91; Wright 1992:313). From a redemptive-historical perspective one could connect God's promises, made in the Old Testament dispensation, with their fulfilment by him in Jesus Christ in line with the promise-fulfilment model to understand the relationship between the two Testaments (König 1989:182$189)$, advocated in reformed theology since the 16th century (Graafland 1992:83-99)..$^{42}$ Accordingly, the promise of a new future, related to the golah by Haggai $(2: 6-9 ; 21-23)$, has been fulfilled in Jesus Christ, Who as to his human nature was a descendent of David and Who through the Spirit of holiness was declared with power to be the Son of God (Rm 1:3-4). In Romans 8:19-22 Paul does not anthropologically reduce eschatology to a doctrine about the future liberation of the believers out of this world in order to live as bodiless souls

40.For a comprehensive treatment of eschatology in the New Testament, cf. Van der Watt (2011).

41.We follow Rose (2000) in his non-messianic interpretation of Haggai 2:21-23.

42.Cf. Hasel (1982:145-168) for a critical assessment of this model within modern scholarship. Cf. also Wielenga (1998a:18-19; 1994:228-232) for an adjustment of this model from a canon-historical perspective. This implies that one reads the Bible from the Old towards the New Testament before one reverses into the opposite direction from the New towards the Old Testament. This modifies a too opposite direction from the New towards the Old Testament. This modifies a too
uncomplicated view on the New Testament fulfilment of Old Testament promises. in heaven. He teaches a future salvation of God's people together with redeemed created reality, with a new heaven and earth as result, upon which resurrected people will live in their imperishable bodies filled with the power of the Holy Spirit (1 Cor 15:20-23, 42-44; Rev 21). In 1 Corinthians 15 there is no doubt in Paul's mind that there is an indestructible bond between the bodily resurrection of Christ and the renewal of creation together with the resurrection of the dead at Christ's parousia. In Christ the promised future had already arrived, which created a new expectation and hope for the complete fulfilment of the promise Haggai (2:9) already proclaimed. Paul announces that the fulfilment will take place when Jesus has defeated the last enemy, death, and hands over the kingdom to his Father (1 Cor 15:24-26). In short, the structure of Haggai's eschatology - the interdependency between past, present and future of redemptive history - we re-encounter in Paul's, whilst content-wise the discontinuity between Haggai and someone like Paul, however stark it may seem to be, does not interrupt this continuity. The coherence of redemptive history, which is given with the progressive nature of divine revelation (De Jong 2013:19-26), guarantees kerugmatic unity in biblical eschatology.

\section{The temple - God's future residence}

Haggai's eschatological prophecy supplied his dejected people with new energy to continue their rebuilding of the temple. The message of the future glory of the temple meant to evoke their obedient commitment to its reconstruction. As we have seen, God's gracious presence in the temple amongst them in the present guaranteed their future. The God who promised to be with them and to bless them in the present, is the One who will be with them in the future, also in the midst of the turmoil of a cosmos being shaken and the world map being redrawn. This future event has been described by Haggai with images familiar from the eschatological language of hope. But the crisis will have a positive result, that is that the nations will be attracted to pilgrimage to Zion to worship Israel's God together with his people, enjoying lasting peace granted by God. In the New Testament this theme has been taken up as well. Several points need to be considered.

In the New Testament the temple in Jerusalem is clearly replaced by Jesus Christ as the temple, in which God dwells in his fullness (Jn 2:19-20; Col 1:19). In the Early Church Isaiah 66:1-2 was quoted against the permanency of the existent temple and its worship, and focused the attention on Jesus Christ as its fulfilment (Acts 7:49). ${ }^{43}$ The permanent presence of Jesus on earth amongst his people is affirmed by John (14:15-20, 23), who specifically refers to the Holy Spirit, the Paraclete (Van Houwelingen 1997:297-298; Veenhof 1974), as the mode in which Jesus is present amongst his disciples. König (1989:143, 145) uses the term functional identity to describe the relationship between the risen Christ and the Spirit in the postpentecost reality. The apostle Paul

43.Isaiah 66:1-2 did not agitate against rebuilding the temple; but redemptive historically, in Acts 7:49 its transitional significance becomes clear: now the fulfilment in Christ has arrived. 
develops this concept further, and states that the church, being the body of Christ, is the temple where the Holy Spirit dwells (1 Cor 3:16-17; 6:19; 2 Cor 6:16; Versteeg 1971:200201). God, who dwelled in the temple of Jerusalem in the Old Testament dispensation, dwells since the resurrection of Jesus Christ and the outpouring of the Spirit on Pentecost in the church (Acts 2:4, 42-47;1 Pt 2:9-10). The old promise of God's presence amongst his people, also confirmed by Haggai (2:4), has been fulfilled in the incarnation of God's Son (Mt 1:23), and is being fulfilled, pneumatologically, by the risen Christ, the Head of his church (Eph 1:23).

Concerning the shaking of heaven and earth $(\mathrm{Hg} 2: 6,21)$, one could associate this image with the shaking of the earth at the time of Jesus' death (Mt 27:51-53). ${ }^{44}$ This theologically significant shaking with its cosmic dimensions, parallel with the opening of the tombs, anticipated the resurrection of Jesus Christ, ending the power of death and initiating the new era of everlasting peace, which will arrive at the parousia, when the dead will also rise bodily. ${ }^{45}$ Haggai also envisaged this sequence of first the cosmic shaking and then, after the pilgrimage of the nations to Zion, the advent of worldwide peace. It is good to notice that also in the apocalyptic events accompanying Jesus' death, the emphasis is on its salvific aspects, not on judgement as its consequence. Here also eschatology and Christology are interdependent.

The promise of eschatological peace that God was going to grant in the temple ( $\mathrm{Hg} 2: 9)$, is going to be fulfilled by Jesus (Jn 14:27), who leaves his disciples with his messianic peace (Is 9:6-7), which is not of this world (Jn 18:36; Van Houwelingen 1997:304), even though it is fully thought of in creatural and not in spiritualised terms. This eschatological peace can already be proleptically anticipated ${ }^{46}$ by the church, which proclaims the good news of the advent of this peace to the world (Is 52:7; Rom 10:14-17). Again, eschatology and Christology are linked together. The source of eschatological peace is the risen Christ, the temple not built by human hands, but the temple by whom the messengers of the good news of peace and salvation have been sent out (Is 52:7; Mt 28:18-20; Rom 10:14) to reach out to the nations.

This leads to a last consideration: the arrival of the nations in Jerusalem to bring God, being in residence in the temple, apart from their worship, also their treasures and wealth; this is a recurring theme also in apocalyptic literature, alluding to the famous plundering of the Egyptians (Ex 12:35-36; Ezr 1:4). This arrival refers to the pilgrimage of the nations we read about in the prophetic traditions. It is envisaged by Haggai as preceding the granting of peace in the temple. This finds

44.Earthquakes did occur in ancient Palestine, even though this one must have been divinely timed. Using apocalyptic language to describe the event, Matthew elicited clearly enough the theological significance of the unusual event here described (Hagner 1995:849-851; Morris 1992:724-725).

45.In 2 Peter 3:5-7, 13 the image of the shaking of heaven and earth has been apocalyptically transformed into one of their cosmic meltdown, preceding final judgement but especially the beginning of cosmic peace, cf. Revelation 20:11; 21:1 judgement but especially the beginn
(Van Houwelingen 1993:89-94).

46.For the terminology, coined by W. Pannenberg, cf. Schwarz (2000:143-146; also Van den Brink \& Van der Kooi 2012:239, 645). confirmation in the eschatological speech of Jesus in Mark 13, where he stresses that the end will come after the gospel have been preached to all the nations (Mt 24:14; Mk 13:10). ${ }^{47}$ There is, however, a serious discontinuity between the New Testament and the Old Testament with regard to mission. Elsewhere (Wielenga 2002:111-119) it is argued that the prophecy of the pilgrimage of the nations to Zion to worship God has not come true. The prophecy expected the positive response of God's people in the process of its fulfilment. Israel failed to reflect God's glory in the world, which would have attracted the nations (Is 60-62). Jesus attempted to restore the fallen tent of David (Acts 15:6), to save the lost sheep of Israel (Mt 10:6; 15:24) in his ministry, assisted by his disciples on their mission trip (Mt 10); he focused exclusively on the Jews, but it ended with his rejection and death on the cross. A prophecy is not a prediction that infallibly comes true, whatever the human response to it may be. In the postexilic era in approximately 480 все Malachi had to rebuke the golah because of their failure to worship God in the temple according to his will. There was nothing to be found in Jerusalem to attract the nations to Zion! The covenantal character of biblical religion implies that the responses and responsibilities of God's people in the fulfilment process have to be taken seriously indeed (Wielenga 1998a). Faithful to his promise of old in Genesis 12:3, God took a radically new initiative to reach out to the nations, as is described in Mathew 28, where the mandate for centrifugal mission is given by the risen Christ. They have to come to the temple, embodied by Jesus Christ, represented by the Spirit-driven church, to become part of the ecclesia adorans. In short, the centripetal mission, envisaged by the prophets, has been aborted and replaced on divine initiative by the centrifugal mission, of which the apostle Paul became its first and most famous representative. ${ }^{48}$

\section{The present - prolepsis of the future}

Coming to the end of our explorations, lastly attention will be pay to the influence of the eschatological future on the people of God living in the in-between times in line with Haggai's description of that influence in his days. The expectation of the future glory of God in the temple in Jerusalem was supposed to activate and energise the golah to complete the temple reconstruction and to live accordingly as a worshipping nation around it before the eyes of the watching world nearby (Samaritans) and far off (Persians). This leads one to make two suggestions for a homiletic application. Firstly, life in the present age, important as it is in God's eyes, should be lived positively as a step into the expected future. Secondly, life should be lived trustfully, in assurance of the providential care of God, who keeps the future in his hands.

Haggai's encouragement of the dejected temple builders, rating the result of their early efforts as negligible $(\mathrm{Hg} 2: 3)$, received support from his colleague Zechariah, who points 47.Cf. Wielenga (1998a:285) for a discussion on mission as sign of the endtime. 48.For the missiological terms centripetal and centrifugal, see Bosch (1979:79-83). 
to God's Spirit as the driving force behind this project. No reason at all, therefore, to despise the day of small things (Zch $4: 6,10)$. The modest start should be seen in the light of what has been promised (Van der Woude 1984:85-92). This conviction, rooted in the eschatological vision of both prophets, is re-encountered in the different New Testament traditions. Right at the end of the apostle Paul's stirring chapter on eschatological hope (1 Cor 15) he admonishes his readers to stand firm in the present age, where what is perishable and mortal rules supreme under the authority of the already-defeated enemy, Death, who, however, still prowls around as a roaring lion (1 Pt 5:8-9). But in this present age they have to be unmoveable in their hope on the final advent of Jesus Christ, giving, therefore, themselves fully in the work of the Lord in the knowledge that their labour in the Lord is not in vain (1 Cor 15:58). Sanctified by the Spirit, they live their lives in the presence of their King (1 Th 3:3-12), waiting with impatient patience for his last advent, when he will hand back his kingly rule to his Father (1 Cor 15:24), their hope and expectation controling their words and actions (1 Th 5:13-17). In Revelation 14:13 God's people are encouraged by the saying that their deeds will follow them into the age of peace to come. Christians have to stand positively in this world (1 Tm 4:1-5). The Christian activities mentioned in these eschatological sayings are often small-scale, not aiming at Christian empire building, Christianising cultures, baptising secular concepts of the makeability of the world as happened in the Liberation theology of the 1970s (cf. Schwarz 2000:152-161). The age of peace to come will not be ushered in by the sanctified fellow workers of Jesus Christ (2 Cor 3:5-6); they will rather be its recipients, only anticipating proleptically in the present age the peace to come, brought about by God himself. Jesus comprehensively summarised Christian life and work in the interim in all its aspects with the term 'witnessing to him' ${ }^{49}$ It implies a persistent struggle against the forces rallying against Christ and his future, breaking consistently and perpetually with a past in which one fell short of God's covenantal expectations (2 Cor 6:1-2).

Lastly, the promise of providential care we may hope for in the turbulent times ahead (Mt 24), before the final advent of the Son of Man, is confirmed in all tradition streams of the New Testament (Schwarz 2000:183-187). ${ }^{50}$ In Haggai $(1: 13 ; 2: 4 ; 2: 9 ; 2: 23)$ the temple builders received their sustenance from the presence of God, Who promised to be with them also in the times to come. With reason we today turn to the church, that is the body of Christ, in whom God fully dwells, the temple of the Spirit, Who is the driving force behind the ministries of the church, where he equips the people for service within and without (1 Cor 12-14).

49.For a discussion of the significance of eschatological hope in the present time, cf Berkhof (1993:509-512); Berkouwer (1972); Schwarz (2000); Van den Brink and Van der Kooi (2012:638-680).

50.In the Gospels we find the warning to keep watch and to be on our guard (M $24: 36-42 ; 25: 1-13$ ) because of the unspecified length of the time we have to wait for the parousia to happen, which will unexpectedly take place like the sudden arrival of a thief in the night. John $(14: 1-4 ; 16: 15-17,25-26)$ adds the assurance that the Paraclete will be of assistance in the interim.
The church as ecclesia adorans is united with Christ in its liturgical worship, where God speaks to his people through his Word, and where at the Lord's table (the Eucharist) the past, present and future of redemptive history are celebrated in commemoration of Christ's ministry on earth (1 Cor 11:23-26). The eschatological hope of the church is sustained right here (Wielenga 1998a:277-278), where God's people taste in the elements of bread and wine the promised peace in communion with their crucified Lord. Just as in his presence at his table the break with the past in repentance becomes visible (1 Cor 10:14-22; 11:27-28), the commitment in the present to Christ as Lord is evident, and the hope on the advent of our risen Lord sustained. At the Lord's table the heart of the ecclesia adorans is found, but not less the centre of the ecclesia laborans in its missiones and vocationes in the world (Wielenga 1998a:246, 255-256)..$^{51}$

\section{Acknowledgements Competing interests}

The author declares that he has no financial or personal relationship(s) that may have inappropriately influenced him in writing this article.

\section{References}

Assis, E., 2008, 'The temple in the book of Haggai', Journal of Hebrew Scriptures 8(19), 2-10. http://dx.doi.org/10.5508/jhs.2008.v8.a19

Assis, E., 2009, 'Psalm 127 and the polemic of the rebuilding of the temple in the postexilic period', Zeitschrift für alttestamentichen Wissenschaft 121(2), 256-272.

Bauckham, R. \& Hart, T., 1999, Hope against hope: Christian eschatology at the turn of the millennium, Eerdmans, Grand Rapids.

Berkhof, H., 1993, Christelijk geloof: Een inleiding tot de geloofsleer, 7th edn., Callenbach, Nijkerk.

Berkouwer, G.C., 1966, De Heilige Schrift, vol. 1, Kok, Kampen. (Dogmatische studien).

Berkouwer, G.C., 1972, The return of Christ, Eerdmans, Grand Rapids. (Studies in Dogmatic).

Berquist, J.L., 1995, Judaism in Persia's shadow: A social and historical approach Fortress, Minneapolis.

Blenkinsopp, J., 2003, Isaiah 56-66, Doubleday, New York. (Anchor Bible Commentary 19B)

Boda, M.J., 2003, 'Zechariah, master mason or penitential prophet?', in R. Albertz \& B. Becking (eds.), Yahwism after exile: Perspectives on Israelite religion in the Persian era, pp. 55-68, Royal van Gorcum, Assen. (Studies in theology and religion 5).

Boda, M.J., 2004, The NIV Application Commentary: Haggai, Zechariah, Zondervan, Grand Rapids.

Boda, M.J., 2010, 'Legitimizing the temple: The Chronicler's temple building account', in M.J. Boda, M.J. \& J. Novotny (eds.), From the foundations to the crenellations: Essays on temple building in the Ancient Near East and Hebrew Bible, pp. 303-318, Ugarit-Verlag, Münster. (Alter Orient und Altes Testament 366).

Boda, M.J. \& Redditt, P.L. (eds.), 2008, Unity and disunity in Ezra-Nehemiah: Redaction, rhetoric, and reader, Phoenix Press, Sheffield. (Hebrew Bible Monographs, 17).

Bosch, D.J., 1979, Heil vir die wêreld: Die Christelike sending in teologiese perspektief, NG Kerkboekhandel, Pretoria.

Canadian Reformed Churches, 1987, 'Form for the celebration of the Lord's Supper', in Book of praise: Anglo-Genevan Psalter, rev. edn., Premier Printing, Winnipeg.

Carvalho, C.L., 2008, 'Finding a treasure map: Sacred space in the Old Testament', in C.M. Bechtel (ed.), Touching the altar: The Old Testament for Christian worship, pp. 123-153, Eerdmans, Grand Rapids.

Childs, B.S., 1985, Old Testament theology in canonical context, SCM, London.

Collins, J.J., 1987, The apocalyptic imagination: An introduction to the Jewish matrix of Christianity, Cross Roads, New York.

Collins, J.J., 2003, 'The eschatology of Zechariah', in L.L. Grabbe \& R.D. Haak (eds.), Knowing the end from the beginning: The prophetic, the apocalyptic and their relationships, pp. 74-84, Clark International, London. (Journal for the Study of Pseudepigrapha 46)

51.See form for the celebration of the Lord's Supper (Canadian Reformed Churches 1987:594-602) for the theological-confessional background of this view on the Lord's table (cf. also GKSA 2001:121-128). 
De Jong, H., 2002, Van oud naar nieuw: De ontwikkelingsgang van het Oude naar het Nieuwe Testament, Kok, Kampen.

De Jong, H., 2013, Eén Bijbel - twee Testamenten, of het ongelijk van Marcion, Van Wijnen, Franeker.

Dekker, J., 2009, 'De leesbril van Henk de Jong: Overwegingen bij het zandlopersmodel', in J. Bouma, F. Gerkema \& J. Mudde (reds.), Verrasend vertrouwd: Een halve eeuw verkondiging en theologie van Henk de Jong, pp. 102-116, Van Wijnen, Franeker.

Eskenazi, T.C., 1988, In an age of prose: A literary approach to Ezra-Nehemiah Scholars Press, Atlanta.

Floyd, M.H., 1995, 'The nature of the narrative and the evidence of redaction in Haggai', Vetus Testamentum 45(4), 470-490. http://dx.doi.org/10.1163/15685 33952662397

Floyd, M.H., 2008, 'Traces of tradition in Zechariah 1-8: A case study', in M.J. Boda \& M.H. Floyd (eds.), Tradition in transition: Haggai and Zechariah 1-8 in the trajectory of Hebrew theology', pp. 210-234, Clark, New York. (Old Testament trajectory of Hebrew theology', pp.
Studies / Library Hebrew Bible 475).

Gereformeerde Kerke in Suid-Afrika, 2001, Psalmboek: Die berymde en omgedigte Psalms en ander Skrifberymings, NG Kerk-Uitgewers, Wellington.

GKSA, see Gereformeerde Kerke in Suid-Afrika.

Gowan, D.E., 2000, Eschatology in the Old Testament, 2nd edn., Clark, Edinburgh.

Graafland, C., 1992, Van Calvijn tot Comri: Oorsprong en ontwikkeling van de leer van het verbond in het Gereformeerd Protestantisme dl. 1 \& 2, Boekencentrum, Zoetermeer.

Grabbe, L.L., 1998, Ezra-Nehemiah, Routledge, London.

Grabbe, L.L. \& Haak, R.D. (eds.), 2003, Knowing the end from the beginning: The prophetic, the apocalyptic and their relationship, Clark International, London.

Greidanus, S., 1970, Sola Scriptura: Problems and principles in preaching historical texts, Kok, Kampen.

Greidanus, S., 1988, The modern preacher and the ancient text: Interpreting and preaching biblical literature, Eerdmans, Grand Rapids.

Hagner, D.A., 1995, World biblical commentary 33B: Matthew 14-28, World Books Publisher, Dallas.

Hanson, P.D., 1975, The dawn of apocalyptic, Fortress, Philadelphia.

Harrington, H.K., 2008, 'Holiness and purity in Ezra-Nehemiah', in M.J. Boda \& P.L. Redditt (eds.), Unity and disunity in Ezra-Nehemiah: Redaction, rhetoric and reader, Sheffield Phoenix Press, Sheffield. (Hebrew Bible Monographs, 17)

Hasel, G., 1982, Old Testament theology: Basic issues in the current debate, 3rd edn., Eerdmans, Grand Rapids.

Hildebrand, D.R., 2010, 'Temple ritual: A paradigm for moral holiness in Hagga 2:10-19, Vetus Testamentum 39(2), 154-168. http://dx.doi.org/10.1163/1568 2:10-19, Vetus
53389x00039

Hurowitz, V.A., 2010, "Solomon built the temple and completed it": Building the first temple according to the book of kings', in M.J. Boda \& J. Novotny (eds.), From the foundations to the crenellations: Temple building in the Ancient Near East the foundations to the crenellations: Temple building in the Ancient Near East Testament 366).

Japhet, S., 1982, 'Sheshbazzar and Zerubbabel: Against the background of the Hebrew and religious tendencies of Ezra-Nehemiah', Zeitschrift für alttetstamentlichen Wissenschaft 94, 66-98.

Japhet, S., 1991, 'The temple in the restoration period: Reality and ideology, Union Seminary Quarterly Review 44, 195-251.

Japhet, S., 1994, 'Composition and chronology in the book of Ezra-Nehemiah', in T.C. Eskenazi \& K.H. Richards (eds.), Second temple studies, vol. 2: Temple community in the Persian period, pp. 189-216, JSOT Press, Sheffield. (Journal for the Study of the Old Testament Supplement Series 175).

Karrer-Grube, C., 2003, 'Scrutinizing the conceptual unity of Ezra-Nehemiah', in M.J. Boda \& P.L. Redditt (eds.), Unity and disunity in Ezra-Nehemiah: Redaction, rhetoric, and reader, pp. 136-159, Phoenix Press, Sheffield. (Hebrew Bible Monographs, 17).

Kessler, J., 2002, The book of Haggai: Prophecy and society in early Persian period Royal Brill, Leiden. (Vetus Testamentum 91).

Kessler, J., 2008, 'Tradition, continuity and covenant in the book of Haggai: An alternative voice from early Persian Yehud', in M.J. Boda \& M.H. Floyd (eds.) Tradition in transition: Haggai and Zechariah 1-8 in the trajectory of Hebrew theology, pp. 1-39, Clark, New York. (Old Testament Studies / Library Hebrew theology, pp.
Bible 475).

Kessler, J., 2010, 'Temple building in Haggai: Variations on a theme', in M.J. Boda, M.J. \& J. Novotny (eds.), From the foundations to the crenallations: Essays on temple \& . Novotny (eds.), From the foundations to the crenallations: Essays on temple
building in the Ancient Near East and Hebrew Bible, pp. 357-380, Ugarit-Verlag, building in the Ancient Near East and Hebrew Bible
Münster. (Alter Orient and Altes Testament 366).

Klement, H.H., 2012, 'Haggai: Prophet of the new temple', in H.G.L. Peels \& S.D. Snyman (eds.), The lion has roared: Theological themes in the prophetic literature of the Old Testament, pp. 175-182, Pickwick Publications, Eugene.

Knoppers, G.N., 2007, 'Nehemiah and Sanballat: The enemy without or within?', in O. Lipshits, G.N. Knoppers \& R.A. Albertz (eds.), Judah and the Judaeans in the fourth century BCE, pp. 305-331, Eisenbrauns, Winona Lake.

Koch, K., 1967, 'Haggais unreines Volk', Zeitschrift für alttestamentlichen Wissenschaft 79, 52-66.

König, A., 1989, The eclypse of Christ in eschatology: Toward a Christ-centered approach, Eerdmans, Grand Rapids.
Koole, J.L., 1983, 'Het Oude Testament als heilige Schrift', in M.J. Mulder, B.J. Oosterhoff, J. Reiling, H.N. Ridderbos \& W.C. van Unnik (reds.), Bijbels handboek, 2 B: Tussen Oude en Nieuwe Testament, pp. 192-246, Kok, Kampen.

Lessing, R.R., 2010, 'Amos' earthquake in the Book of the Twelve', Catholic Theological Quarterly 74, 243-259.

Lipschits, O. \& Blenkinsopp, J. (eds.), 2003, Judah and the Judaeans in the Neo-Babylonian period, Eisenbrauns, Winona Lake.

Lux, R., 2009, Prophetie und Zweiter Temple: Studien zu Haggai und Sacharja, Mohr Siebeck, München. (Forschungen zum Alten Testament 65).

McDonald, L.M. \& Sanders, J.A. (eds.), 2002, The canon debate, Hendrickson, Peabody.

Meyers, C.L. \& Meyers, E.M., 1987, Haggai, Zechariah 1-8, Doubleday, New York. (Anchor Bible Commentary 25B)

Miller, P.D., 1990, Deuteronomy, John Knox Press, Louisville.

Morris, L., 1992, The gospel according to Matthew, Eerdmans, Grand Rapids. (The Pillar New Testament Commentaries)

Noort, E., 1984, 'Toekomstverwachting in het Oude Testament - Enkele aspecten', in H. Baarlink, W.S. Duvekot \& A. Geense (reds.), Vervulling en voleinding: De toekomstverwachting in het Nieuwe Testament, pp. 13-29, Kok, Kampen.

Nykolaishen, D.J.E., 2008, 'The restoration of Israel by God's Word in three episodes from Ezra-Nehemiah', in M.J. Boda \& P.L. Redditt (eds.), Unity and disunity in EzraNehemiah: Redaction, rhetoric, and reader, pp. 176-199, Phoenix Press, Sheffield. (Hebrew Bible Monographs 17).

Peels, H.G.L., 1999, 'Eschatologie in het Oude Testament', in W. van 't Spijker (red.), Eschatologie: Handboek over de christelijke toekomstverwachting, pp. 9-50, De Groot-Goudriaan, Kampen.

Pikänen, P., 2010, 'Temple building and Exodus 25-40, in M.J. Boda \& J. Novotny (eds.), From the foundations to the crenellations: Essays on temple building in the Ancient Near East and Hebrew Bible, pp. 255-280, Ugarit-Verlag, Münster. (Alter Orient und Altes Testament 366).

Pola, T., 2003, 'Form and meaning in Zechariah 3', in R.A. Albertz \& B. Becking (eds.), Yahwism after exile: Perspectives on Israelite religion in the Persian era, pp. 156-167, Royal van Gorcum, Assen. (Studies in theology and religion 5).

Rendtorff, R., 2011, The canonical Hebrew Bible: A theology of the Old Testament, 2nd edn., Deo Publishing, Blandford Forum. (Tools for Biblical Studies series, 7).

Rose, W.H., 2000, Zemah and Zerubbabel: Messianic expectations in the early postexilic period, Sheffield Academic Press, Sheffield. (Journal for the Study of the Old Testament Supplement Series 304)

Rose, W.H., 2012, 'Zachariah: Prophet of the king of Jerusalem and all the earth', in H.G.L. Peels \& S.D. Snyman (eds.), The lion has roared: Theological themes in the prophetic literature of the Old Testament, pp. 183-196, Pickwick Publications, Eugene.

Rose, W.H., 2013, 'Toekomst voor de koning: Het koningschap in het boek Zachariah', in K. van Bekkum, P.H.R. van Houwelingen \& H.G.L. Peels (reds.), Nieuwe en oude dingen: Schatgraven in de Schrift, pp. 213-230, Vuurbaak, Barneveld. oude dingen: Schatgraven in de Schrift, pp.
(Apeldoornse Studies 62; TU Bezinningsreek 13).

Schaudig, H., 2010, 'The restoration of temples in the Neo- and Late Babylonian period', in M.J. Boda \& J. Novotny (eds.), From the foundations to the crenellations: Temple building in the Ancient Near East and Hebrew Bible, pp. 141-164, UgaritVerlag, Münster. (Alter Orient und Altes Testament 366).

Schmitt, R., 2003, 'Gab es einen Bildensturm nach dem Exil? Bemerkungen zum Verwendung von Terrakottafigurinen im nach-exilischen Israel', in R.A. Albertz \& B. Becking (eds.), Yahwism after exile: Perspectives on Israelite religion in the Persian era, pp. 186-198, Royal van Gorcum, Assen. (Studies in theology and religion 5).

Schwarz, H., 2000, Eschatology, Eerdmans, Grand Rapids.

Strauss, H.S.W. \& De Wet, F.W., 2014, 'Hermeneutiese uitdagings aan christocentrische prediking vanuit die Ou-Testamentiese narratiewe', In die Skriflig/In Luce Verbi 48 20 p., Art. \#1717.

Throntveit, M.A., 1992, Ezra-Nehemiah, John Knox Press, Louisville.

Tollington, J.E., 1993, Tradition and innovation in Haggai and Zechariah 1-8, ISOT Press, Sheffiled. (Journal for the Study of the Old Testament Supplement JSOT Press,
Series 150).

Van den Brink, G. \& Van der Kooi, C., 2012, Christelijke dogmatiek: Een inleiding, 2nd edn., Boekencentrum, Zoetermeer.

Van der Toorn, K., 2007, Scribal culture and the making of the Hebrew Bible, Harvard University Press, Cambridge.

Van der Watt, J.G., (ed.), 2011, Eschatology of the New Testament and some related documents, Mohr Siebeck, Tübingen. (Wissenschaftliche Untersuchungen zum Neuen Testament 2 315).

Van der Woude, A.S., 1984, Zacharia, Callenbach, Nijkerk. (Prediking Oude Testament).

Van Houwelingen, P.H.R., 1993, 2 Petrus, Judas: Testament in tweevoud, Kok, Kampen. (Commentaar Nieuwe Testament 3).

Van Houwelingen, P.H.R., 1997, Johannes: Het evangelie van het Woord, Kok, Kampen. (Commentaar Nieuwe Testament 3).

Van Keulen, D., 2003, Bijbel en dogmatiek: Schriftbeschouwing en schriftgebruik in het dogmatische werk van A. Kuyper, H. Bavinck en G.C. Berkouwer, Kok, Kampen

Van Rooy, H.F., 1988, 'Eschatology and audience: The eschatology of Haggai', Old Testament Essays, new series 1(1) 49-63.

Veenhof, J., 1974, De parakleet: Enige beschouwingen over de parakleet-belofte in het evangelie van Johannes en haar theologische betekenis, Kok, Kampen. 
Versteeg, J.P., 1971, Christus en de Geest: Een exegetisch onderzoek naar de verhouding van de opgestane Christus en de Geest van God volgens de brieven verhouding van de opges
van Paulus, Kok, Kampen.

Versteeg, J.P., 1975, 'De toekomst van de schepping: Paulus' apocalyptisch spreken over de schepping in Romeinen 8:19-22', in T. Baarda, J. Firet \& G.Th. Rothuizen (reds.), Ad Interim: Opstellen over eschatologie, apocalyptiek en ethiek, pp. 80-95, Kok, Kampen. (Festschrift R. Schippers).

Von Rad, G., 1965, Theologie des Alten Testaments, 2, Kaiser Verlag, München.

Westermann, C., 1969, Isaiah 40-66, Westminster Press, Philadelphia. (Old Testament Library).

Wielenga, B., 1992, 'The Bible in a changing South Africa: The quest for a responsible biblical hermeneutic in mission', Missionalia 20(1), 28-37.

Wielenga, B., 1994, 'Zendingshermeneutiek: Een inleiding', in J. Bouma, J. Dekker, A.M. van Leeuwen \& K. Muller (reds.), Begeleidend schrijven: 25 jaar theologische studiebegeleiding, pp. 227-232, Buijten \& Schipperheijn, Amsterdam.

Wielenga, B., 1998a, Verbond en zending: Een verbondsmatige benadering van zending, Mondiss, Kampen.

Wielenga, B., 1998b, 'Oud en Nieuw Verbond: Contingentie en coherentie in de verbondsgeschiedenis', In die Skriflig/In Luce Verbi 32(3), 333-348.
Wielenga, B., 2002, 'Mission and the apocalyptic: A perspective from Matthew', International Review of Mission 41(360), 111-119. http://dx.doi.org/10.1111/ j.1758-6631.2002.tb00333.x

Wielenga, B., 2010, 'Bible reading in Africa: The shaping of a reformed perspective', In die Skriflig/In Luce Verbi 44(3\&4), 699-721.

Wielenga, B., 2013, 'Renewal and restoration: Holy writ in Ezra-Nehemiah - A missional reading, In die Skriflig/In Luce Verbi 47(1), 1-13.

Witherington, B. III, 1999, Jesus the Seer: The progress of prophecy, Hendrickson, Peabody.

Wolff, H.W., 1986, Dodekapropheton 6: Haggai, Neukirchener Verlag, Neukirchen. (Biblischer Kommentar Altes Testament 14[6]).

Wright, C.H.J., 2001, The message of Ezekiel, InterVarsity, Leicester. (Bible Speaks Today).

Wright, C.H.J., 2006, The mission of God: Unlocking the Bible's grand narrative, InterVarsity Academic, Downers Grove.

Wright, N.T., 1992, The New Testament and the people of God, Fortress, Minneapolis. (Christian origins and the question of God, vol. 1)

Zimmerli, W., 1969, Ezechiel 2, Neukirchener Verlag, Neukirchen-Vluyn. (Biblischer Kommentar Altes Testament 13[2]). 